\title{
THE LIPID CONTENT OF BOVINE SPERMATOZOA DURING MATURATION AND AGEING*
}

\author{
U. LAVON, $\uparrow$ R. VOLGANI AND D. DANON $\ddagger$ \\ Department of Animal Science, Volcani Institute of Agricultural Research, Rehovot, Israel, \\ and $\ddagger$ The Weizmann Institute of Science, Rehovot, Israel \\ (Received 11th October 1969, revised 16th April 1970)
}

Summary. Several changes occurring during sperm maturation in the epididymis were determined either for spermatozoa obtained from consecutive ejaculates or from the caput and the cauda epididymidis.

A significant decline was found in the fresh weight of the cells during maturation and was attributed to dehydration and to a loss of certain components from the cells. This was proved by the increase in the $\%$ dry matter and by the decrease in the content of the dry matter, the total lipids and of the main lipid fractions of the cells during maturation.

The increase in the \% dry matter and the decrease in the \% total lipids in the dry matter explain the increase in the specific gravity of spermatozoa during maturation.

\section{INTRODUGTION}

The importance of the lipids and the lipid fractions (cholesterol and phospholipids) in the process of maturation of spermatozoa passing through the male genital tract was demonstrated by several investigators (Scott, Dawson \& Rowlands, 1963; Dawson \& Scott, 1964; Grogan, Mayer \& Sikes, 1966; Pickett, Komarek, Gebauer, Benson \& Gibson, 1967; Quinn \& White, 1967; Scott, Voglmayr \& Setchell, 1967; Scott \& Dawson, 1968). These workers showed that a decrease in phospholipids and cholesterol content in sperm cells occurs during maturation in the epididymis. Pickett \& Komarek (1967) found a higher lipid content in the dry matter of spermatozoa obtained from the second consecutive ejaculate than in those from the first one.

It was reported that the specific gravity (sp.gr.) of spermatozoa increases during maturation and ageing (Lindahl \& Kihlström, 1952; Lavon, Volcani, Amir \& Danon, 1966a, b). The increase was attributed by Lindahl \& Kihlström to dehydration, but was later assumed by Lavon, Volcani \& Danon (1968) to be, in addition, the consequence of changes in the chemical composition of the cells.

The present study, which is part of a research project on the biophysical and biochemical properties of maturing spermatozoa, shows the dependence

* Contribution from the Volcani Institute of Agricultural Research, Rehovot, Israel. 1969 Series, No. 1621-E.

$\dagger$ Present address: Animal Research Station, 307 Huntingdon Rd, Cambridge. 
between specific gravity, dry matter and lipid content of spermatozoa of different age groups.

\section{Semen collection}

\section{METHODS}

Ejaculated spermatozoa were collected and separated from the seminal fluid as described by Lavon et al. (1968). Epididymal spermatozoa were collected from the caput and the cauda according to Grogan et al. (1966), and were separated from fluids and foreign matter as described previously (Lavon $e t$ al., 1968).

\section{Sperm counting}

Spermatozoa were counted in an EEL colorimeter (in duplicate) and in a haemocytometer (four counts of each sample).

\section{Specific gravity determination}

The specific gravity of spermatozoa was determined as described by Lavon et al. (1966a), using phthalate esters (product of Miles-Yeda, Rehovot, Israel).

\section{Dry matter determination}

Dry matter was weighed after 24-hr freeze-drying as described by Lavon $e t a l$. (1968).

\section{Lipid extraction}

Extraction and determination of total lipids were based partly on the procedure of Komarek, Pickett, Lanz \& Jensen (1964) and Miller, Mayer \& Merilan (1965), but mainly on that of Terner \& Korsh (1962), using eight homogenizations in a 2:1 (v/v) chloroform:methanol solution. The combined extracts were purified according to Folch, Lees \& Sloane-Stanley (1957). The solvent was removed on a rotary evaporator at $45^{\circ} \mathrm{C}$ and the total lipids were determined gravimetrically after they had cooled for $4 \mathrm{hr}$ in a desiccator over anhydrous sodium sulphate. The lipids were then transferred to a $10-\mathrm{ml}$ flask with the aid of diethyl ether and the volume was adjusted. This solution served as a stock for cholesterol and phospholipid determination.

\section{Cholesterol determination}

Duplicates of $1.5 \mathrm{ml}$ of the stock solution were saponified according to Abell, Levy, Brodie \& Kendal (1952) and the cholesterol was determined by the method of Searcy \& Bergquist (1960).

\section{Phospholipid determination}

Phosphorus in the stock solution was determined by a slight modification of the method of Gomori (1942). Phosphorus values were multiplied by 25 to give the phospholipid content.

\section{Statistical analysis}

The results for each of the parameters were subjected to a two-way analysis 
of variance (in one way, the consecutive ejaculates or the caput and cauda epididymidis and in the second, the individual bulls) according to Snedecor (1948). The standard error (S.E.) of the means for the ejaculates or the caput and cauda and the least significant difference (L.S.D.) at the $5 \%$ level were given when significant differences were found.

\section{EXPERIMENTAL PROGEDURE}

\section{Experiment 1 : ejaculated spermatozoa}

The specific gravity, \% dry matter, $\%$ total lipids in the dry matter, and $\%$ cholesterol and phospholipid in the sperm total lipid were determined. Four ejaculates were collected from each of five Israel-Friesian bulls, 3 to 4 years old, following 20 days of abstinence.

\section{Experiment 2: spermatozoa from caput and cauda epididymidis}

The $\%$ dry matter, total lipid in the dry matter, and cholesterol and phospholipid in the total lipid, were determined. The spermatozoa were obtained from ten bulls, 14 to 16 months old, immediately after slaughter.

\section{Experiment 3: spermatozoa from caput and cauda epididymidis}

This experiment included the determination of fresh and dry weights, lipids and lipid fractions of spermatozoa collected from six bulls, 14 to 16 months old, immediately after slaughter.

\section{RESULTS}

\section{Experiment 1}

The amounts of semen and of total dry matter obtained in the third and fourth consecutive ejaculates were relatively small ( 20 to $25 \mathrm{mg}$ total dry matter in the fourth) due to the low concentration of spermatozoa in those ejaculates. It was only possible to obtain reliable results for the \% total lipids in the dry matter and of cholesterol and phospholipids in the total lipids for three consecutive ejaculates (Table 1). In the fourth ejaculate, however, it was possible to make accurate determinations of the specific gravity and \% dry matter (specific gravity has even been determined for five consecutive ejaculates, Lavon et al., 1966a).

In order to carry out further investigations on the fourth ejaculate, semen was collected from another set of five bulls selected because their third and fourth ejaculates contained sufficient dry matter to permit reliable results from an analysis of the \% total lipid (Table 2 ).

From Table 1, it can be seen that the specific gravity increased from the first to the second consecutive ejaculate and decreased from the second to the fourth. A similar trend was observed in the \% dry matter, although the differences between the ejaculates were not significant. The $\%$ total lipid in the dry matter increased from the first to the third ejaculate. A significant decrease from the first to the third ejaculate was found for the $\%$ cholesterol and phospholipid in the total lipid. 
TABLE 1

SPECIFIC GRAVITY VALUES AND \% DRY MATTER FOR SPERMATOZOA COLLEGTED IN FOUR CONSECUTIVE EJACULATES; \% TOTAL LIPID IN THE DRY MATTER; AND \% CHOLESTEROL AND PHOSPHOLIPID IN THE TOTAL LIPID FOR SPERMATOZOA GOLLEGTED IN THREE CONSEGUTIVE EJAGULATES FROM EAGH OF FIVE BULLS FOLLOWING 20 DAYS OF ABSTINENCE

\begin{tabular}{|c|c|c|c|c|c|c|}
\hline \multirow{2}{*}{ Parameter } & \multicolumn{4}{|c|}{ Ejaculate } & \multirow{2}{*}{$\begin{array}{c}\text { S.E. of } \\
\text { ejaculate } \\
\text { means }\end{array}$} & \multirow{2}{*}{$\begin{array}{l}\text { L.S.D. } \\
5 \%\end{array}$} \\
\hline & First & Second & Third & Fourth & & \\
\hline $\begin{array}{l}\text { Sp. gr. } \\
\% \text { dry matter } \\
\% \text { total lipid } \\
\% \text { cholesterol } \\
\% \text { phospholipid }\end{array}$ & $\begin{array}{l}1.0842 \\
31.09 \\
11.61 \\
10.80 \\
50.68\end{array}$ & $\begin{array}{c}1.0909 \\
32 \cdot 52 \\
13.47 \\
9.95 \\
46.37\end{array}$ & $\begin{array}{l}1 \cdot 0809 \\
32 \cdot 31 \\
16 \cdot 23 \\
7 \cdot 71 \\
38 \cdot 68\end{array}$ & $\begin{array}{c}1.0772 \\
32 \cdot 04 \\
= \\
=\end{array}$ & $\begin{array}{l} \pm 0.001 \\
\text { NS } \\
\pm 0.97 \\
\pm 0.56 \\
\pm 1.64\end{array}$ & $\begin{array}{l}0.003 \\
\overline{3 \cdot 16} \\
1 \cdot 82 \\
5 \cdot 33\end{array}$ \\
\hline
\end{tabular}

NS = not significant.

TABLE 2

THE SPECIFIC GRAVITY, \% DRY MATTER AND \% TOTAL LIPID IN THE DRY MATTER IN SPERMATOZOA COLLECTED IN FOUR CONSECUTIVE EJACULATES FROM EACH OF FIVE BULLS FOLLOWING 20 DAYS OF ABSTINENGE

\begin{tabular}{|c|c|c|c|c|c|c|}
\hline Parameter & First & $\begin{array}{c}E j \\
\text { Second }\end{array}$ & Third & Fourth & $\begin{array}{l}S . E . \text { of } \\
\text { ejaculate } \\
\text { means }\end{array}$ & $\begin{array}{c}\text { L.S.D. } \\
5 \%\end{array}$ \\
\hline $\begin{array}{l}\text { Sp. gr. } \\
\% \text { dry matter } \\
\% \text { total lipid }\end{array}$ & $\begin{array}{l}1.0904 \\
31.62 \\
12.06\end{array}$ & $\begin{array}{l}1 \cdot 0871 \\
31 \cdot 31 \\
14 \cdot 15\end{array}$ & $\begin{array}{l}1.0856 \\
31 \cdot 43 \\
14.88\end{array}$ & $\begin{array}{l}1.0796 \\
31.95 \\
15.03\end{array}$ & $\begin{array}{l} \pm 0.0017 \\
\mathrm{NS} \\
\pm 0.66\end{array}$ & $\begin{array}{l}0.005 \\
2.02\end{array}$ \\
\hline
\end{tabular}

NS $=$ noţ significant.

The results given in Table 2 confirm those of Table 1, but are extended to the fourth ejaculate.

\section{Experiment 2}

The data collected in this experiment are presented in Table 3.

A significant increase in the $\%$ dry matter from caput to cauda epididymidis was found, as reported previously by Lavon et al. (1968). The \% total lipid in the

TABLE 3

THE \% DRY MATTER, TOTAL LIPID IN THE DRY MATTER AND GHOLESTEROL AND PHOSPHOLIPID IN THE TOTAL LIPID IN SPERMATOZOA COLLECTED FROM GAPUT AND GAUDA EPIDIDYMIDIS OF TEN BULLS, 14 TO 16 MONTHS OLD, IMMEDIATELY AFTER SLAUGHTER

\begin{tabular}{l|c|c|c|c}
\hline Parameter & $\begin{array}{c}\text { Caput } \\
\text { epididymidis }\end{array}$ & $\begin{array}{c}\text { Cauda } \\
\text { epididymidis }\end{array}$ & $\begin{array}{c}\text { S.E. of } \\
\text { means }\end{array}$ & $\begin{array}{c}\text { L.S.D. } \\
5 \%\end{array}$ \\
\hline$\%$ dry matter & 29.87 & 33.53 & \pm 0.55 & 1.62 \\
$\%$ total lipid & 20.00 & 15.02 & \pm 0.49 & 1.45 \\
$\%$ cholesterol & 9.64 & 9.94 & NS & - \\
$\%$ phospholipid & 52.64 & 49.18 & NS & - \\
\hline
\end{tabular}

NS $=$ not significant. 
dry matter was significantly higher for spermatozoa from the caput than for the cauda. No significant differences were observed in the \% cholesterol and phospholipid in the total lipid, although a trend towards a decrease in the latter was noted.

\section{Analysis of results}

Data of the chemical composition of spermatozoa are generally presented either as $\%$ fresh weight, $\%$ dry matter, or as quantity for a given number of cells. Analysing the data of the different parameters obtained in the present study, it was essential to compare the results by different methods of calculation.

TABLE 4

THE \% TOTAL LIPID, CHOLESTEROL AND PHOSPHOLIPID IN THE FRESH WEIGHT OF SPERMATOZOA FROM THE SAME SEMEN SAMPLES GIVEN IN TABLES 1 AND 2

\begin{tabular}{|c|c|c|c|c|c|}
\hline \multirow{2}{*}{ Parameter } & \multicolumn{4}{|c|}{ Ejaculate } & \multirow{2}{*}{$\begin{array}{l}\text { S.E. of of } \\
\text { ejaculatate } \\
\text { means }\end{array}$} \\
\hline & First & Second & Third & Fourth & \\
\hline $\begin{array}{l}\% \text { total lipid (1) } \\
\% \text { cholesterol (1) } \\
\% \text { phospholipid (1) } \\
\% \text { total lipid (2) }\end{array}$ & $\begin{array}{l}3.54 \\
0.41 \\
1 \cdot 80 \\
3.79\end{array}$ & $\begin{array}{l}4 \cdot 21 \\
0 \cdot 45 \\
1.95 \\
4 \cdot 43\end{array}$ & $\begin{array}{l}5 \cdot 15 \\
0 \cdot 43 \\
2 \cdot 03 \\
4 \cdot 68\end{array}$ & $\frac{\bar{z}}{4 \cdot 83}$ & $\begin{array}{c}\text { NS } \\
\text { NS } \\
\text { NS } \\
\pm 0 \cdot 22 *\end{array}$ \\
\hline
\end{tabular}

NS $=$ not significant.

*L.S.D. $5 \%=0.68$.

(1) and (2) refer to Tables 1 and 2, respectively.

TABLE 5

THE \% TOTAL LIPID, CHOLESTEROL AND PHOSPHOLIPID IN THE FRESH WEIGHT OF EPIDIDYMAL SPERMATOZOA FROM THE SAME SAMPLES GIVEN IN TABLE 3

\begin{tabular}{l|c|c|c|c}
\hline Parameter & $\begin{array}{c}\text { Caput } \\
\text { epididymidis }\end{array}$ & $\begin{array}{c}\text { Cauda } \\
\text { epididymidis }\end{array}$ & $\begin{array}{c}\text { S.E. of } \\
\text { means }\end{array}$ & $\begin{array}{c}\text { L.S.D. } \\
5 \%\end{array}$ \\
\cline { 1 - 3 }$\%$ total lipid & 5.96 & 5.04 & \pm 0.15 & 0.47 \\
$\%$ cholesterol & 0.57 & 0.49 & \pm 0.02 & 0.07 \\
$\%$ phospholipid & 3.10 & $2 \cdot 48$ & \pm 0.10 & 0.31 \\
\hline
\end{tabular}

While the $\%$ total lipids in the dry matter showed an increase from the first to the third or fourth consecutive ejaculate (Tables 1 and 2 respectively), the \% cholesterol and the phospholipid in the total lipid decreased (Table 1). The data are represented as \% fresh weight in Table 4 for the consecutive ejaculates and in Table 5 for the epididymal spermatozoa. The total lipid showed the same tendency as was found for its content in the dry matter, but it was found to be significant only for the data presented in Table 2. No differences were observed in the $\%$ cholesterol, and the phospholipid showed a tendency similar to that of the total lipid, i.e. an increase from the first to the third ejaculate. Both findings are contrary to the trends observed when they were expressed as their percentage in the total lipid. It seems that the \% neutral lipid increases when the 
estimation is based on the total lipid, and decreases when calculated as a percentage of the fresh weight of the cells.

The data for the epididymal spermatozoa show a significant decrease in all the parameters (Table 5).

The fresh weight may not be an appropriate basis for calculating the chemical changes which occur in the spermatozoa proper. During maturation and ageing, the \% dry matter in the fresh weight of the cells increases due to dehydration. It was, therefore, assumed that changes in the fresh weight of the cells also occur. An estimation of the changes that take place in individual cells was needed.

\section{Experiment 3}

This was designed to compare experimental results based upon fresh weights and dry weights in $\mathrm{mg} / 10^{9}$ cells. It can be concluded (Table 6) that a significant

TABLE 6

FRESH AND DRY WEIGHT, LIPIDS, CHOLESTEROL AND PHOSPHOLIPID CONTENT IN EPIDIDYMAL SPERMATOZOA COLLECTED FROM SIX BULLS IMMEDIATELY AFTER SLAUGHTER

\begin{tabular}{|c|c|c|c|c|}
\hline Parameter & $\begin{array}{c}\text { Caput } \\
\text { epididymidis }\end{array}$ & $\begin{array}{c}\text { Cauda } \\
\text { epididymidis }\end{array}$ & $\begin{array}{l}S . E . \text { of } \\
\text { means }\end{array}$ & $\begin{array}{l}L . S . D . \\
\mathbf{5} \%\end{array}$ \\
\hline $\begin{array}{l}\text { Fresh weight (mg/109 cells) } \\
\text { Dry weight (mg/109 cells) } \\
\% \text { dry matter } \\
\text { Total lipid (mg } / 10^{9} \text { cells) } \\
\% \text { lipids (in fresh weight) } \\
\% \text { lipids (in dry matter) } \\
\text { Cholesterol (mg/10 } / 10^{9} \text { cells) } \\
\% \text { cholesterol (in fresh weight) } \\
\% \text { cholesterol (in total lipid) } \\
\text { Phospholipids (mg } / 10^{9} \text { cells) } \\
\% \text { phospholipid (in fresh weight) } \\
\% \text { phospholipid (in total lipid) }\end{array}$ & $\begin{array}{r}104 \cdot 30 \\
32 \cdot 40 \\
30 \cdot 46 \\
5 \cdot 64 \\
5 \cdot 41 \\
17 \cdot 61 \\
0 \cdot 58 \\
0 \cdot 55 \\
10 \cdot 34 \\
2 \cdot 73 \\
2 \cdot 62 \\
48 \cdot 78\end{array}$ & $\begin{array}{r}79 \cdot 30 \\
26 \cdot 50 \\
33 \cdot 15 \\
3 \cdot 84 \\
4 \cdot 81 \\
14 \cdot 57 \\
0 \cdot 41 \\
0 \cdot 52 \\
10 \cdot 85 \\
1 \cdot 90 \\
2 \cdot 39 \\
49 \cdot 99\end{array}$ & $\begin{array}{l} \pm 2 \cdot 12 \\
\pm 0 \cdot 35 \\
\pm 0.54 \\
\pm 0 \cdot 20 \\
\text { NS } \\
\text { NS } \\
\pm 0.03 \\
\text { NS } \\
\text { NS } \\
\pm 0 \cdot 07 \\
\pm 0.05 \\
\text { NS }\end{array}$ & $\begin{array}{l}7 \cdot 69 \\
1 \cdot 36 \\
2 \cdot 11 \\
0.72 \\
\overline{-} \\
0 \cdot 10 \\
\overline{-} \\
0 \cdot 24 \\
0 \cdot 16 \\
-\end{array}$ \\
\hline
\end{tabular}

NS $=$ not significant.

Results are expressed in $\mathrm{mg} / 10^{9}$ cells, as the percentage in the fresh weight and as the percentage in the dry matter or in the total lipid.

decrease occurs both in the fresh, and the dry weight of the cells as they pass from caput to cauda. The decrease in the total lipids and in the lipid fractions was found to be significant only when the data were calculated as $\mathrm{mg} / 10^{9}$ cells. In addition, the \% phospholipid in the fresh weight decreased significantly. A trend towards a decrease in the neutral lipid was also noted (as calculated from the difference between the total lipid and the main lipid fractions).

\section{DISCUSSION}

A significant decline occurred in the fresh weight of the sperm cells during their maturation. This decline might be attributed to two factors: dehydration, and a decrease in the dry matter content. The latter may be a result of the metabolic utilization of phospholipids as a source of energy (Quinn \& White, 1967; 
Scott et al., 1967). The decrease found in this work in the dry weight of the cells during maturation is contrary to the findings of Gledhill (1966), who reported a constant dry mass of the sperm head during its passage through the epididymis. It is also different from the observations of Pickett et al. (1967) on the boar. They reported a higher dry matter content for the ejaculated than for the epididymal spermatozoa of this animal. As the decrease in the dry matter content is relatively smaller than that of the water content, it results in an increase in the $\%$ dry matter.

It seems that the decrease in the fresh and dry weight of the sperm cells causes a reduction in their size. This has been reported for red blood cells, using the Coulter counter (Leif \& Vinograd, 1964; van Gastel, van den Berg, de Gier \& van Deenen, 1965) and recently for bull and ram spermatozoa (O'Donnell, 1969).

A significant decrease was found in the total lipids and in the main lipid fractions during maturation in the epididymis. This decrease was found both with consecutive ejaculates and with epididymal spermatozoa. These findings agree with reports by other workers (Scott et al., 1963; Dawson \& Scott, 1964; Grogan et al., 1966; Pickett \& Komarek, 1967; Pickett et al., 1967; Quinn \& White, 1967; Scott et al., 1967).

The increase in the \% dry matter and the decrease in $\%$ total lipid explain the increase in the specific gravity values reported previously (Lindahl \& Kihlström, 1952; Lavon et al., 1966a, b).

\section{ACKNOWLEDGMENTS}

This study has been financed in part by a grant awarded by the United States Department of Agriculture under P.L. 480. The authors are indebted to Mr D. Zismann for his technical assistance.

\section{REFERENCES}

Abell, L. L., Levy, B. B., Brodie, B. B. \& Kendal, F. E. (1952) A simplified method for the estimation of total cholesterol in serum and demonstration of its specificity. F. biol. Chem. 195, 357.

Dawson, R. M. C. \& ScotT, T. W. (1964) Phospholipid composition of epididymal spermatozoa prepared by density gradient centrifugation. Nature, Lond. 202, 292.

Folch, J., LeEs, M. \& Sloane-Stanley, G. H. (1957) A simple method for the isolation and purification of total lipids from animal tissues. F. biol. Chem. 206, 497.

GLedhill, B. L. (1966) Studies on the DNA content, dry mass and optical area of bull spermatozoal heads during epididymal maturation. Acta vet. scand. 7, 131.

Gomori, G. (1942) A modification of the colorimetric phosphorus determination for use with the photoelectric colorimeter. F. Lab. clin. Med. 27, 955.

Grogan, D. E., Mayer, D. T. \& Sikes, J. D. (1966) Quantitative differences in phospholipids of ejaculated spermatozoa and of spermatozoa from three levels of the epididymis of the boar. J. Reprod.Fert. 12, 431 .

Komarex, R. J., Pickett, B. W., Lanz, R. N. \& Jensen, R. G. (1964) Lipid composition of bovine spermatozoa and seminal plasma. F. Dairy Sci. 47, 531 .

Lavon, U., Volcani, R., Amir, D. \& Danon, D. (1966a) The specific gravity of bull spermatozoa and seminal plasma. F. Reprod. Fert. 11, 447.

Lavon, U., Volcani, R., Amir, D. \& Danon, D. (1966b) The specific gravity of bull spermatozoa from different parts of the reproductive tract. $\mathcal{F}$. Reprod. Fert. 12, 597.

Lavon, U., Volcani, R. \& Danon, D. (1968) Determination of dry matter percentage of ejaculated and epididymal bull spermatozoa after differential flotation. 7 . Reprod. Fert. 17, 151. 
LeIF, R. C. \& Vinograd, J. (1964) The distribution of buoyant density of human erythrocytes in bovine albumin solutions. Proc. natn. Acad. Sci., U.S.A. 51, 520.

Lindaht, P. E. \& KirLström, J. E. (1952) Alterations in specific gravity during the ripening of bull spermatozoa. 7. Dairy Sci. 35, 393.

Miller, L. D., Mayer, D. T. \& Merilan, G. P. (1965) Lipid classes of bovine spermatozoa. F. Dairy Sci. 48, 395.

O'Donnelt, J. M. (1969) Electronic counting and sizing of mammalian spermatozoa and cytoplasmic droplets. F. Reprod. Fert. 19, 263.

Pickett, B. W. \& Komarek, R. J. (1967) Lipid and dry weight of bovine seminal plasma and spermatozoa from first and second ejaculates. F. Dairy Sci. 50, 742.

Pickett, B. W., Komarek, R. J., Gebauer, M. R., Benson, R. W. \& Gibson, E. W. (1967) Lipid and dry weight of ejaculated, epididymal and post-castrate semen from boars. F. Anim. Sci. 26, 792.

Quinn, P. J. \& Whrte, I. G. (1967) Phospholipid and cholesterol content of epididymal and ejaculated ram spermatozoa and seminal plasma in relation to cold shock. Aust. F. biol. Sci. 20, 1205.

ScotT, T. W. \& Dawson, R. M. C. (1968) Metabolism of phospholipids by spermatozoa and seminal plasma. Biochem. F. 108, 457.

Scotr, T. W., Dawson, R. M. C. \& Rowlands, I. W. (1963) Phospholipids interrelationships in rat epididymal tissue and spermatozoa. Biochem. . . 87, 507.

Scott, T. W., Voglmayr, J. K. \& Setcheld, B. P. (1967) Lipid composition and metabolism in testicular and ejaculated spermatozoa. Biochem. F. 102, 456.

SeArcy, R. L. \& Bergquist, L. M. (1960) A new color reaction for the quantitation of serum cholesterol. Clinica chim. Acta, 5, 192.

SNedecor, G. W. (1948) Statistical methods. The Iowa State College Press, Ames, Iowa.

TRRner, G. \& Korsh, G. (1962) The biosynthesis of $\mathrm{C}^{14}$ labelled lipids by isolated bull spermatozoa. Biochemistry, $1,367$.

van Gastre, C., van den Berg, D., de Grer, J. \& van Deenen, L. L.M. (1965) Some lipid characteristics of normal red blood cells of different age. Br. F. Haemat. 11, 193. 